\title{
Reinterpreting Religious Pluralism in QS. al-Baqarah: 62 (A Method of al-Qaradâwî's Interpretation)
}

\author{
Muhammad Kudhori, Muhammad Faiq, Ibnu Farhan \\ Univertsitas Islam Negeri Walisongo Semarang, Indonesia \\ kudhori@walisongo.ac.id
}

\begin{tabular}{c}
\hline Article \\
Information \\
\hline
\end{tabular}

Submitted: September, 08, 2020

Revised I: November, 07, 2020

Revised II: June, 26, 2021

Accepted: November, 04, 2021

\section{Keywords}

Pluralism, method of interpretation, al-Qaraḍ̂awî, salvation.

\section{Abstract}

QS. al-Baqarah: 62 by some Muslim scholars is used to justify that adherents of all religions in this world will get salvation and go to paradise. Salvation in the hereafter, according to them, is not required to believe in the Prophet Muhammad. This article aimed to re-examine that interpretation that is contrary to the belief of the majority of Muslims, in which one aspect of faith that will save people is a belief in the messengers, including a belief in the Prophet Muhammad. The reinterpretation of QS. al-Baqarah: 62 in this study employed the interpretation method of Yûsuf al-Qarad̂âtwi in his book entitled Kayfa Nata 'âmal Ma' al-Qur'ân al- 'Azîm. This article is a library based-study by using content analysis and descriptive-analytic. The result revealed that QS. al-Baqarah: 62 actually deals with the earlier peoples before the Prophet Muhammad. Those who believe in Allah and the Last Day and do good deeds are promised a reward from Allah SWT.

\section{Abstrak}

QS. al-Baqarah: 62 oleh sebagian kalangan dijadikan sebagai dalil bahwa pemeluk semua agama yang ada di dunia ini kelak akan selamat dan masuk surga. Keselamatan di akhirat menurut kelompok ini tidak diharuskan beriman kepada Nabi Muhammad Saw. Artikel ini bermaksud menelaah kembali penafsiran tersebut yang tentu bertentangan dengan keyakinan mayoritas umat Islam, dimana salah satu aspek iman yang dapat menyelamatkan umat manusia adalah beriman kepada para rasul, termasuk beriman kepada Muhammad Saw. Telaah kembali atas tafsir QS. al-Baqarah: 62 dilakukan dengan 
menggunakan metode penafsiran Yûsuf al-Qaraḍ̂wî dalam kitabnya yang berjudul Kayfa Nata 'âmal Ma 'al-Qur'ân al- 'Aẓ̂m. Metode yang digunakan dalam tulisan ini adalah studi kepustakaan (library research) dengan analisis data menggunakan content analysis dan deskriptifanalitis. Hasilnya, QS. al-Baqarah: 62 sebenarnya berbicara tentang umat-umat terdahulu sebelum Nabi Muhammad Saw. diutus. Mereka yang beriman kepada Allah Swt dan hari akhir, serta beramal saleh dijanjikan pahala oleh Allah Swt.

\section{Introduction}

There are two kinds of Quranic interpretation (tafsîr), i.e., tafsîr bi al-ma'tsûr and tafsîr bi al-ra'y. Tafsîr bi al-ma'tsûr is interpreting the verses of the Qur'an using other verses of the Qur'an, the traditions of the Prophet SAW., the interpretation of the Companions (Sahâbah), and the interpretation of the followers (Tabi'in). The weakness of such interpretation is many invalid narrations and the Isra'iliyyat narrations used to interpret Qur'anic verses. In contrast, tafsîr bi al-ra' $y$ is the interpretation of the Qur'an by employing more on reason. In its development, tafsîr bi al-ra'y is divided into two: mahmûd (commendable) and madzmûm (despicable).

Deviations in the Quranic interpretation can occur by only taking one verse of the Qur'an, then ignoring the other verses or related Hadith. In the history of the Khawarij, it can be seen how the Khawarij interpreted the Qur'an according to their understanding, which has created radical movements, causing the killing of the fourth Caliph, Ali bin Abi Talib. They took one verse to justify their understanding but ignored another verse. The Khawarij, for example, used the verse "In al-Hukm IllâLillâh" as proof to justify their actions to disbelieve the companions involved in tahkim (arbitration) and those who executed 'Alî bin Abî Tâlib. They forget other verses that justify tahkîm. ${ }^{1}$

In the contemporary era, tasykîk (question) towards Islamic teachings has occurred several

${ }^{1}$ The legality of tahkîm in the Qur'an is mentioned in QS. alNisa' (4): 35 and al-Ma'idah (5): 95. times by Muslim intellectuals and academicians in the name of tajdid of religious teachings or new scientific findings. For example, some of Mun'im Sirry's writings support same-sex marriage if it is based on consensual relationships. ${ }^{2}$ In an international seminar forum, 1st International Conference on Islamic Studies held by STAIN Pamekasan on 21-22 October 2017 at Hotel Front One Pamekasan, Mun'im Sirry also stated that to be safe and go to heaven, one must not believe in Muhammad Saw. In his view, the Christians, Jews, and Sâbi'în will also enter paradise along with the believers. Mun'im Sirry, like Jalaluddin Rakhmat, ${ }^{3}$ refers to QS. al-Baqarah 62. ${ }^{4}$

\footnotetext{
${ }^{2}$ Mun'im Sirry wrote an article entitled: "Islam, LGBT dan Perkawinan Sejenis". This article was published by inspiration. co on February 20, 2016 and republished by TEMPO.CO on March 2, 2016. The article published on Tempo.co can be accessed at the following link:

https://indonesiana.tempo.co/read/64822/2016/03/02/masirry/ islam-lgbt-dan-perkawinan-sejenis. Meanwhile, on inspiration. co, this article is no longer accessible.

${ }^{3}$ Jalaluddin Rahmat's argument can be seen in a video spread on You Tube when he expressed his views on pluralism in a seminar organized by the Postgraduate Program of UIN Bandung. The video can be seen on link: https://www.youtube.com/ watch?v=1Zqyo5xhXsk. See also Jalaluddin Rakhmat, Islam dan Pluralisme: Akhlak Quran Menyikapi Perbedaan (Jakarta: Serambi, 2006), 22-29.

${ }^{4}$ The view that all religions are the same has been around for a long time. Ibn 'Arab (558-638 H.), in his book Fuṣ̂s al-Hikam states that all religions are the same. He warned the readers of his book not to limit the belief to a certain religion and then disbelieve in other beliefs because that would result in the loss of a lot of goodness. According to al-Sya' rânî as quoted by 'Abd alHalîm al-Najjâr in the footnote of Madzâhib al-Tafsîr al-Islâmî, Ibn'Arabî's statement is a madsûs (insertion) that the enemies of Islam deliberately carried out to disrupt Islam. Or it could be that Ibn'Arabî's statement above is a statement that comes out of his subconscious, a kind of syațhâât (delirium) that comes out of people who are not exposed to taklif. But if the statement is true from Ibn'Arabî in a conscious state, then in the view of 'Abd al-Halîm al-Najjâr, he has changed the Religion of Allah and the
} 
In his book entitled Islam dan Pluralisme: Akhlak Qur'an Menyikapi Perbedaan, Rakhmat presented an argument for religious pluralism by quoting the opinions of two Mufassir from the Ahlul Bait (Shia) circles, namely Sayyid Huseyn Fadlullah and from the Ahlusunnah circles, namely Rasyid Ridha when both of them interpreted Surah al-Baqarah: 62. Rakhmat then stated that the verse supports religious pluralism. The verse does not state that all religions are true but emphasizes that all believers will be safe as long as they believe in Allah, the Last Day, and do good deeds. ${ }^{5}$ In his book, Rakhmat also denies the exclusive people who said: 1) The verse is mansûkh (annulled, erased) by Surah Âli 'Imrân: 85. He refutes this argument by quoting Sayyid Husseyn Fadhlullah opinion that the verse does not contradict al-Baqarah: 62. What is meant by "Islam" contained in Ali Imran: 85 is Islam in a broad sense, which includes the treatise (risâlah) of the sky, not Islam in the sense of a religion brought by the Prophet Muhammad, 2) The verse comprises Jews, Christians, and Sabian in ancient times before the Prophet Muhammad Saw. Arguments with this kind of analogy, according to Rakhmat, are said to have no basis that strengthens them both in the Qur'an and Hadith, and 3) What is meant by believing in Allah SWT. is faith in Allah in the concept of Islamic teachings, as the God of Muslims. Rakhmat refutes this argument by presenting the verses that state that the God of the adherents of different religions is Allah, as stated in QS. alAnkabut: 46 and 61 and al-Zukhruf: $87 .{ }^{6}$

What Jalaluddin Rakhmat and Mun'im Sirry said above certainly contradicts the belief of

\footnotetext{
Shari'a of Muhammad SAW. Such kind of belief is certainly not the belief of Muslims (See Ibn 'Arabî, Fușûs al-Hikam [t.tp.: Dâr al-Kitâb al-'Arabî, n.d.], 113-114.); Muhammad Yûsuf alQaraḍ̂wî, Kayf Nata 'âmal Ma' al-Qur'ân al-'Aẓ̂m [Kairo: Dâr al-Syurûq, 1999], 274-275.); Ignaz Goldziher, Madzâhib alTafsîr al-Islâmî, ed. 'Abd al-Halîm al-Najjâr [Kairo: Maktabah al-Sunnah al-Muhammadiyyah, 1955], 206-207).

5Jalaluddin Rakhmat, Islam dan Pluralisme: Akhlak Quran Menyikapi Perbedaan (Jakarta: Serambi, 2006), 22-23. ${ }^{6}$ Ibid., 30-32.
}

the majority of Muslims about the concept of salvation in the hereafter that only Muslims who believe in the Prophet Muhammad and his treatise will be safe. This belief is in accordance with the verses of the Qur'an and the hadith of the Prophet. ${ }^{7}$

Studies on religious pluralism in the sense of assuming salvation in the hereafter for all religions have actually been carried out by several academicians. Zahrodin Fanani, a student of the Master degree in Islamic Thought at the Graduate School of the University of Muhammadiyah Surakarta, wrote a thesis entitled "Pandangan Muhammad Rasyid Ridâ tentang Pluralisme di Tafsir al-Manar". This thesis specifically explores Riḍâ's opinion and interpretation of the verses that are claimed to justify religious pluralism. The study found that Rasyid Rida never acknowledged and justified religious pluralism. ${ }^{8}$ This conclusion is certainly different from Rida's view which is often quoted by religious pluralism activists as if he is a supporter of religious pluralism.

Faidah Umami, in her thesis entitled "Pluralisme Agama dalam al-Qur'an (Komparasi Pemikiran Abdul Muqsith Ghazali dengan Ali Mustafa Ya'qub terhadap Ayat-ayat Pluralistik" explains that the tolerance initiated by Abdul Muqsith approaches "religious pluralism" which is defined as a notion that all religions are equal and all have the right to go to heaven, but not as free as John Hick's religious pluralism opposed by MUI. Meanwhile, Ali Mustafa Yakub was against the notion of religious pluralism in the

${ }^{7}$ See QS. Âli Imrân (3): 19, 85 and also the saying of the prophet:

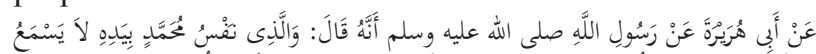

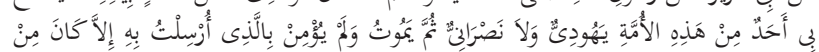
أَصْحَابِ النَّارِ.

"By the One who holds the soul of Muhammad, no one heard me from this ummah, whether Jews or Christians, then he died and did not believe in the treatise that I brought except he will be one of the inhabitants of hell"'(Muslim bin al-Hajjâj al-Naysâbûrî, alJâmi 'al-Șaḥ̂ḥ, Vol. 1 [Beirut: Dâr al-Jayl, n.d.], 93).

${ }^{8}$ Zahrodin Fanani, "Pandangan Muhammad Rasyid Ridha Terhadap Pluralisme Agama dalam Tafsir al-Manar" (Thesis, Postgraduate Program of Universitas Muhammadiyah Surakarta, 2013). 
sense that all religions are equal. Yakub used the hadith of the Prophet Muhammad, which explained that Jews and Christians who do not believe in Muhammad's message would later go to hell as stated in al-Baqarah: $62 .{ }^{9}$

Muhammad Syukri, in his thesis entitled "Pluralisme dalam Perspektif Mufassirin" concludes that the Mufassirs agree on the reality of religious plurality in the Qur'an. But they argue that the true religion is Islam. This study does not explicitly interpret al-Baqarah: 62 but rather focuses on the Tafsir of Ibn Katsîr, Sayyid Quṭb and Quraysh Shihab. ${ }^{10}$

Ahmad Khoirul Fata and Fauzan wrote an article entitled "Kritik INSISTS terhadap Gagasan Pluralisme Agama". In the view of INSISTS, Islam is the last religion brought by the Prophet Muhammad which must be followed by all people, including the followers of the religion of the previous prophets, so that salvation in the hereafter can only be found in Islam. Related to alBaqarah: 62, which is often used as the reason for religious pluralism by liberal groups, according to INSISTS activists, the verse talks about previous people who lived before Islam. ${ }^{11}$

Fadliyatul Mukhoyaroh and Saifullah wrote "Pluralisme Agama Perspektif Tafsir Al-Misbah karya Muhammad Quraish Shihab". Both of them stated that Quraish Shihab's pluralism is by realizing mutual understanding and respect for other parties as brothers of humanity who live side by side, safely and peacefully, without sacrificing the basic principles of Islam as the true religion. ${ }^{12}$ They only explain Quraish Shihab's view of religious pluralism in Tafsir Al-Misbah,

${ }^{9}$ Faidah Umami, "Pluralisme Agama dalam Al-Qur'an (Komparasi Pemikiran Abdul Muqsith Ghazali dengan Ali Mustafa Ya'qub terhadap Ayat-ayat Pluralistik" (Thesis, Postgraduate Program of IAIN Sunan Ampel, 2013), 143-146.

${ }^{10}$ Muhammad Syukri, "Pluralisme dalam Perspektif Mufassirin" (Thesis, Postgraduate Program of UIN Syarif Kasim Riau, 2017), 153.

${ }^{11}$ Ahmad Khoirul Fata dan Fauzan, "Kritik INSISTS terhadap Gagasan Pluralisme Agama”. Kalam 11, no. 1 (2017): 53-54.

${ }^{12}$ Fadliyatul Mukhoyaroh dan Saifullah, "Pluralisme Agama Perspektif Tafsir Al-Misbah karya Muhammad Quraish Shihab". Multicultural 2, no. 2 (2019): 58. not specifically explaining the interpretation of al-Baqarah: 62.

Then, Siti Hajar and Umayah wrote an article entitled "Tafsir Ayat-ayat Pluralisme Agama Perspektif Husein Muhammad". This article does not specifically discuss Surah al-Baqarah: 62 but Husein Muhammad's views on religious pluralism. According to Husein Muhammad, religious pluralism is a necessity given by God to be understood and practiced by humankind by upholding human values without mixing the teachings of one religion with other religions. In Husein Muhammad's view, pluralism is not about equalizing religions but facilitating religious communities to dialogue and fight for human rights. $^{13}$

Despite the above studies talk about religious pluralism and discuss the interpretation of the QS. al-Baqarah: 62, none of them has studied the interpretation of the QS. al-Baqarah: 62 specifically with the interpretation method of Yûsuf al-Qaraḍ̂âi.

Muhammad Yûsuf al-Qaraḍ̂wî in his book entitled Kayf Nata 'âmal Ma 'al-Qur'ân al- 'Aẓ̂m wrote several rules that must be considered in interpreting the Qur'an to get a proper interpretation in accordance with the objectives of the Qur'an. In al-Qaraḍ̂âî's view, some groups who deviate in understanding the Qur'an are being trapped in following mutasyâbih verses and leaving muhkam verses. Therefore, to understand the mutasyâbih verses, according to al-Qaraḍ̂âi, must refer to the muhkam.

This article tries to describe the interpretation of QS. al-Baqarah: 62 by using the method of interpretation of al-Qaradâwî. The method used in this article is library research with data analysis using content analysis and descriptive-analytic. This article can serve as a critique and challenge several interpretations that conclude that all adherents of religions are the same and will go to

\footnotetext{
${ }^{13}$ Siti Hajar dan Umayah, "Tafsir Ayat-ayat Pluralisme Agama Perspektif Husein Muhammad". Diyấ 'Al-Afkâr 8, no. 02 (2020): 247.
} 
paradise even though they do not believe in the Prophet Muhammad Saw.

\section{Al-Qaradâwî: A Mufassir}

Muhammad Yûsuf al-Qaraḍ̂âi was born in a village in the Arab Republic of Egypt, precisely in the village of Șaft Turâb, al-Maḥallah al-Kubrâ, al-Gharbiyyah district, Egypt. This village is an ancient village where the last Companions of the Prophet SAW died, 'Abdullah bin Hârits was buried. Al-Qaradâwî was born on September 9, 1926 AD. Before ten years, he has perfected the memorization of the Qur'an and its tajwîd (rules of recitation).

Al-Qaradâwî then studied at Ma'had alAzhâr al-Syarîf and completed his Ibtida'iyah and Tsanawiyah education. He always achieved excellence in his study. He then continued to the Faculty of Usuluddin at Al-Azhâr University and graduated in 1952-1953 AD. He became the best among his 180 friends. Al-Qaradâwî obtained an international teaching diploma from Kulliyât al-Lughah al-'Arabiyyah in 1954 AD. He ranked first among fellow graduates from AlAzhâr, which amounted to 500 people. In 1958, he received a Diploma at Ma'had al-Dirâsât al'Âliyah in the field of Language and Literature. In 1960, he obtained a higher preparatory course equivalent to a Master in the study of al-Qur'ân and al-Sunnah from the Faculty of Usûluddîn. In 1973, he received a doctorate with honors from the same university, with his dissertation entitled al-Zakât wa Atsaruhâ fì Halli al-Masyâkil al-Ijtimâ'iyyah (Zakat and its impact in solving social problems). ${ }^{14}$

Al-Qaradâwî is one of the scholars who is very productive in writing. He has published hundreds of books covering various scientific fields, ranging from fiqh and fiqh proposals, Islamic

\footnotetext{
${ }^{14}$ This biography of al-Qaradâwî is quoted from al-Sîrah alDzâtiyyah (biography) of al-Qaradâwî which is published on the official website of al-Qaradâwî at https://www.al-qaradawi.net/ content $/ \% \mathrm{D} 8 \% \mathrm{~A} 7 \% \mathrm{D} 9 \% 84 \% \mathrm{D} 8 \% \mathrm{~B} 3 \% \mathrm{D} 9 \% 8 \mathrm{~A} \% \mathrm{D} 8 \% \mathrm{~B} 1 \% \mathrm{D}$ 8\%A9-\%D8\%A7\%D9\%84\%D8\%B0\%D8\%A7\%D8\%AA\%D9 $\% 8 \mathrm{~A} \% \mathrm{D} 8 \% \mathrm{~A} 9$.
}

economics, Qur'anic science, Hadith science, Islamic theology, da'wah and education, Islamic thought, biographies of scholars, literature, and so on. His works have become a reference for academicians in the world.

Al-Qaraḍ̂âi's works in the field of Qur'anic science and interpretation include Kayfa Nata 'âmal Ma' al-Qur'ân al-'Aẓ̂m. This book contains a guide for every Muslim in interacting with the Qur'an. This book begins with the first chapter, which explains the features and purposes of the Qur'an. The second chapter explains how to interact with the Qur'an through memorizing, reading, and listening to the Qur'an.The third chapter explains how to interact with the Qur'an in the context of understanding and interpreting the Qur'an. While the fourth chapter explains how to interact with the Qur'an in the context of ittiba ', practice and da'wah. ${ }^{15} \mathrm{Al}$-Qaradâwî also wrote $a l$ Marja 'iyyah al- 'Ulyâ Fî al-Islâm Li al-Qur'ân wa al-Sunnah, which contains guidelines and rules in understanding the Qur'an and al-Sunnah. ${ }^{16}$

While in Tafsir, al-Qaraḍ̂wî wrote two works of Tafsir mawdî' $\hat{\imath}$ (thematic) entitled al-Sabr fî al-Qur'ân and al-'Aql wa al-'Ilm fì al-Qur'ân. The lectures delivered by al-Qaraḍ̂wî recently at the 'Umar bin Khatțâb Mosque, Doha also talked a lot about themes in the Qur'an, such as al-Îmân Fî al-Qur'ân, al-Mâl Fî al-Qur'ân, al-Âbâ'wa al-Abnâ'Fî al-Qur'ân, al-Hukm wa al-Siyâsah Fî al-Qur'ân and al-Mar'ah Fî al-Qur'ân. AlQaraḍ̂wî also wrote Tafsîr Sûrat al-Ra'd, Tafsîr Sûrat al-Hijr and Tafsîr Sûrat Ibrâhîm. These three interpretations are derived from the study of interpretations taught by al-Qaradâwî at the alSyuyûkh Mosque (Great Mosque) Doha, Qatar. ${ }^{17}$

Another work of al-Qaradâwî in the field of Tafsir is Tafsîr Juz' 'Amma. Juz' 'Amma itself is

\footnotetext{
${ }^{15}$ See Muhammad Yûsuf al-Qaraḍ̂wî, Kayf Nata 'âmal Ma' alQur'ân al- 'Azî̀m (Kairo: Dâr al-Syurûq, 1999).

${ }^{16}$ See Muhammad Yûsuf al-Qaraḍ̂wî, al-Marja 'iyyah al- 'Ulyâ Fî al-Islâm Li al-Qur'ân wa al-Sunnah (Kairo: Maktabah Wahbah, 2012).

${ }^{17}$ Muhammad Yûsuf al-Qaraḍ̂âi, Tafsîr Juz' 'Amma (t.t.: t.p., n.d.), 4-6. See also at https://www.al-qaradawi.net/node/5054
} 
the juz' of the Qur'an that most Muslims read in their prayers. In addition, Juz' 'Amma is also the juz' that Muslims mostly memorize. It explains a lot about aqidah, morals, da'wah and debates with polytheists. Many scholars have written the commentary on Juz' 'Amma specifically, both from classical and contemporary scholars. One of them is Muhammad Abduh. In writing Tafsîr Juz' 'Amma, al-Qaraḍâwî first mentions the most important maqâșid (objectives) in each surah, then interprets its verses with other verses of the Qur'an as well as combining it with tafsîr bi alriwâyah and bi al-dirâyah. ${ }^{18}$

\section{Al-Qarậâî̀'s Method of Interpreting The Qur'an}

Muhammad Yûsuf al-Qaradâwî, in his book entitled Kayfa Nata 'âmal Ma 'al-Qur'ân al- 'Aẓ̂m explained the rules of interpreting the Qur'an to obtain a proper interpretation in accordance with the objectives of the Qur'an. According to him, to get a good understanding, a mufassir must apply eight rules as follows:

\section{Combining the Tafsîr bi al-Riwâyah and} Dirâyah (al-ra'y)

According to al-Qaradâwî, the most ideal method of interpreting the Qur'an is to combine the interpretation of riwâyah and dirâyah. He quoted al-Syawkâni's opinion that this method was adopted because he saw the interpretation made by the Prophet, through a valid chain. It is also the interpretations made by the companions. Therefore, this kind of interpretation model is a must in interpreting the Qur'an. ${ }^{19}$

In al-Qaradâwî's view, this kind of method is the method that contemporary mufassir should take to get a correct understanding of the Qur'an. He regrets that some contemporary writers ignore

\footnotetext{
${ }^{18}$ Ibid., 6.

${ }^{19}$ Muhammad bin 'Alî al-Syaukânî, Fatḥ al-Qadîr al-Jâmi" Bayna Fannî al-Riwâyah wa al-Dirâyah min 'Ilm al-Tafsîr (Beirut: Dâr al-Ma'rifah, 2007), 10-11. See also Muhammad Yûsuf al-Qaraḍâwî, Kayfa Nata 'âmal..., 218-219.
}

the interpretations of the salaf and khalaf scholars and ignore previous scholars' works. ${ }^{20}$

2. Interpreting the Qur'an with the Qur'an The Qur'an interprets and justifies one verse to another. What is unclearly mentioned in one verse will be explained in another verse. Similarly, what is generally mentioned in verse will be specified in another verse and so on. Interpreting the verses of the Qur' an with other verses is a method taught by the Prophet when he explained the meaning of zulm which the companions misunderstood. ${ }^{21}$

\section{Interpreting the Qur'an with the Sunnah}

Interpreting the Qur'an with al-Sunnah is chosen when a mufassir does not find a verse of the Qur'an to interpret another verse of the Qur'an. One of the functions of al-Sunnah is as an explanation for the Qur'an. Salaf scholars often say that the Qur'an needs al-Sunnah to explain its meaning more than al-Sunnah to the Qur'an. ${ }^{22}$ The reason is that the Qur'an just explains laws globally which are then elaborated and explained by al-Sunnah. The problem that has emerged since a long time ago is that not all Sunnah can be used to explain the Qur'an because not all the Sunnah is maqbîl (acceptable). Therefore, al-Qaraḍ̂wî stated that it requires a validSunnah to interpret the Qur'an. ${ }^{23}$

\section{Using the interpretations of the Companions and Tabi'in}

Companions are people who met and interacted directly with the Prophet. They are the ones who witnessed firsthand the Qur'an was revealed and where it was revealed. Therefore, if there is a valid interpretation from the Companions, then that interpretation must be considered, considering that they are people who directly

\footnotetext{
${ }^{20}$ Muhammad Yûsuf al-Qaraḍ̂âi, Kayf Nata 'âmal..., 219.

${ }^{21}$ Ibid., 220.

${ }^{22}$ Yûsuf bin 'Abd al-Barr al-Namirî, Jâmi' Bayân al-'Ilm wa Faḍlih, Vol. 2 (Beirut: Dâr al-Kutub al-'Ilmiyyah, 1398 H.), 191.

${ }^{23}$ Muhammad Yûsuf al-Qaraḍ̂âi, Kayfa Nata 'âmal..., 224.
} 
know the sabâb al-nuzûl and listen to the Qur'an directly from the Prophet. They are certainly more aware of the context and meaning of the revealed verse. Especially if they agree on the interpretation of a verse, their agreement shows that the interpretation has a strong basis, which is basically the interpretation of al-Sunnah. However, if they have different interpretations of a verse, it is permissible to choose and perform tarjîh in their opinion. It also gives the conclusion that their interpretation of a verse is the product of their fallible ijtihad. ${ }^{24}$

Suppose the interpretation of a verse is not found among the Companions. In that case, a mufassir should refer to the interpretation of the Tabi'in, such as Mujâhid bin Jabr (21-104 H.), Qatâdah (61-118 H.), Sa‘îd bin Jubayr (46 H. -95 H.), Ikrimah (25-105 H.), 'Athâ' (27-114 H.), al-Hasan al-Bașrî (21-110 H.), Masrûq (1 QH-62 H.), Ibn al-Musayyab (15-94 H.), Abû al-'Aliyyah (d. 93 H.), al-Ḍaḥhâk bin Muzâhîm (d. 102 H.) and others. Yet, according to the Companions, the opinions of the Tabi' in who differ from each other cannot be a hujjah (argument). But if they agree on an interpretation, then there is no doubt that their agreement can be hujjah. ${ }^{25}$

\section{Taking the universality of the language}

Allah SWT revealed the Qur'an in Arabic. Therefore, in interpreting the Qur'an, it must also be in accordance with the meaning indicated by the language and its use. Likewise, it must be in accordance with the rules and the balaghah of the Qur'an. Some words in the Qur'an are majâz (metaphor) and musytarâk, which have more than one meaning. The choice of meaning in these words must be made carefully and thoroughly. According to al-Qaradâwî, in taking the generality of language in the Qur'an, several things must be considered, such as keep the meaning of words at the time the Qur'an was revealed, keep the words that are not takhșiș and taqyîd, and must examine

\footnotetext{
${ }^{24}$ Ibid., 229.
}

${ }^{25}$ Ibid., 230. the meaning of the words desired by the Qur' an. ${ }^{26}$

\section{Considering the redaction of the verse}

One of the important rules to get a good understanding of the Qur'an is considering the redaction of the verses used in the surah because some words contained in the Qur'an sometimes have more than one meaning. ${ }^{27}$

\section{Considering asbab al-nuzûl}

The following rule that is no less important in understanding and interpreting the Qur'an is to pay attention to asbâb al-nuzûl. The ulama stated that the verses of the Qur'an are divided into two i.e., the verses that were revealed without asbâb al-nuzîl. Such verses are many. And the verses that were revealed by reason, with the socio-historical background (asbâb al-nuzĥl) and such verses are less. Studying asbâb al$n u z \hat{u} l$, according to the ulama, is a strong way to understand the verses of the Qur'an. ${ }^{28}$

\section{Make the Qur'an a guidance}

The last rule that the mufassir must hold, according to al-Qaradâwî, is that they should keep away from the confines of ideology, school, and thought that surrounds them. Their view of the Qur'an should be like a person who seeks guidance from the Qur'an, completely "naked". They position the Qur'an as the basis that is used as a guide when there is a conflict. They made the Qur'an to be followed, not to follow, as a judge, not to be judged, and as a basis, not a branch. AlQaraḍ̂wî establishes this rule because there are groups who understand or interpret the Qur'an according to the school they adhere to. According to al-Qaradâwî, it is inappropriate to make the Qur'an a follower of the schools of jurisprudence, theology, philosophy, and Sufism. The Qur'an must be positioned above all. It must be a marja

\footnotetext{
26 Muhammad Yûsuf al-Qaraḍ̂âi, Kayfa Nata 'âmal..., 232-237.

${ }^{27}$ Ibid., 240.

${ }^{28}$ Ibid., 249
} 
(reference) and a judge for all. ${ }^{29}$

The eight rules in interpreting the Qur'an conveyed by al-Qaraḍ̂âi above are actually not new. However, al-Qaraḍ̂âi's view above has its own distinctiveness, such as the combination of tafsîr bi al-riwâyah and bi al-dirâyah, the necessity to use authentic hadith to interpret the Qur'an and make the Qur'an as a basis that is free from the confines of certain ideologies and schools of thought.

In addition, al-Qaraḍâwî also notes some things that the mufassir of the Qur'an should avoid. They must follow mutasyâbihât verses and leave muhkamât, bad ta'wîl, putting texts out of place, claiming naskh without evidence, not knowing al-Sunnah and al-Atsâr, just believing in Isrâilliyyât narrations, ignoring Ijmâ ' and weak in mastery Qur'anic sciences. ${ }^{30}$

In al-Qaradâwî's view, several groups who deviate in understanding the Qur'an are because they are trapped in following mutasyâbih verses and leaving muhkam verses. Therefore, in understanding the mutasyâbih verses, according to al-Qaradâwî, they must be returned to muhkam verses.

In interpreting a verse, al-Qaraḍ̂wî does not always apply the eight rules above wholly. He only uses the rules that are found and correlated with the interpreted verse because these eight rules are often not always found in verse. For example, the interpretation of a verse of the Qur'an with another verse is applied if the verse is explained by another verse. Likewise, the use of asbâb al-nuz $\hat{u} l$ is only applied to verses that have asbâb al-nuzûl.

\section{Reinterpretation al-Baqarah: 62 with al- Qaraḍ̂âî's Interpretation Approach}

As stated in the introduction above, QS. al-Baqarah: 62 is often used as an argument by religious pluralism activists. They state that salvation in the hereafter also belongs to adherents

\footnotetext{
${ }^{29}$ Ibid., 256-258.

${ }^{30}$ Ibid., 265-365.
}

of religions outside Islam who do not believe in the Prophet Muhammad and the treatise he brought. In this regard, this opinion will be reviewed by reinterpreting al-Baqarah: 62 using al-Qaraḍ̂âî's interpretation approach.

In the Qur'an Allah SWT. Said:

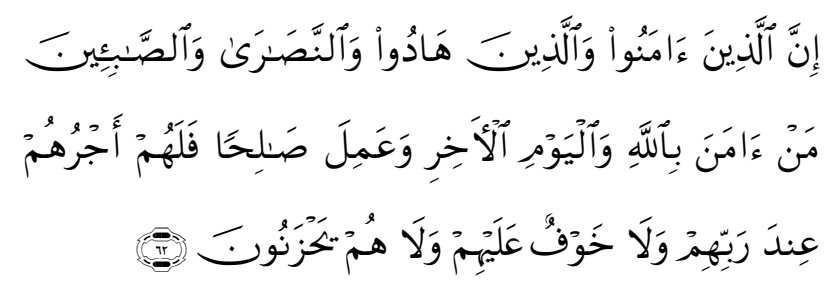

"Surely those who believe and those who are Jews and the Christians and the Sabians, whoever (amongst those) believes in Allah and the Last Day and does righteous deeds (purifies their soul's heart), they shall have their reward with their Lord, and there is no fear for them, nor shall they grieve" [QS. alBaqarah: 62] $]^{31}$

In the view of religious pluralism proponents, ${ }^{32}$ like Jalaluddin Rakhmat and Mun'im Sirry, the above verse is generally accepted, meaning that to be safe and enter paradise, one is not required to believe in Muhammad Saw along with the treatise he brought with him. Jalaluddin Rakhmat quoted the opinions of Sayyid Husein Fadhlullâh and Rasyîd Riḍa to streng then his view. Sayyid Husein Fadhlullâh, in his book entitled Tafsîr Min Wahy al-Qur'ân, when interpreting the verse above, said:

و المعنـي في هذه الاية و اضح. فهـي تؤكد أن النجاح في الاخرة

\footnotetext{
${ }^{31}$ In line with this verse is QS. al-Maidah: 69

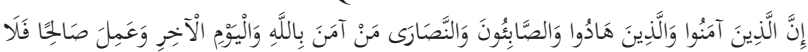

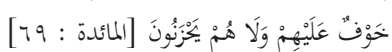

"Indeed, the believers, Jews, Sabiansand Christians - whoever 'truly' believes in Allah and the Last Day and does good, there will be no fear for them, nor will they grieve."

${ }^{32}$ In Nur Syam's view, pluralism is divided into two; theological pluralism and social pluralism. Theological pluralism is the belief that all religions are theologically the same. While social pluralism is the belief that the message of all religions is essentially the same, namely the message of humanity. According to Nur Syam, the pluralism taught by Gus Dur is social pluralism. (See Nur Syam, "Sekali Lagi Pluralisme Gus Dur”'in http://nursyam.uinsby.ac.id/?p=879
} 
تناله كل هذه الفئات الدينية المختلفة في تفكير هاو تصور ها الديني

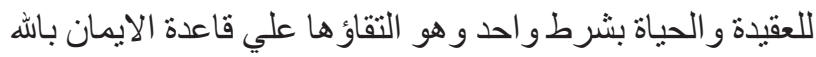
واليوم الاخر و العمل الصالح.

"The meaning of this verse is clear. This verse confirms that salvation in the hereafter will be obtained by all religious groups who differ in their thoughts, religion, and faith but with one condition, namely a meeting of these religious groups with the principles of faith in Allah, in the last day and do good deeds."

Jalaluddin Rahmat also quoted Rasyîd Ridhâ's statement when interpreting the verse above as follows:

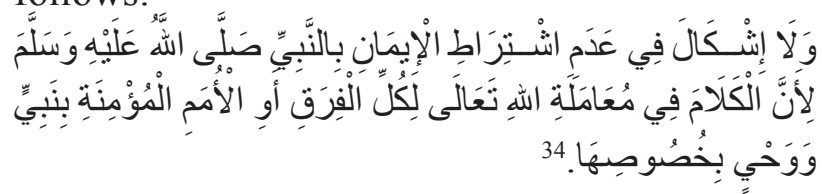

"There is no impossibility inthe absence of conditions for believing in the Prophet because the discussion of this verse is related to the relationship of Allah SWT. with every firqah or people who believe in prophets and revelations. " 35

\footnotetext{
${ }^{33}$ Sayyid Husein Fadhlullâh, Tafsîr min Wahy al-Qur'ân, Vol. 2 (Beirut: Dâr al-Malâk, 1998), 69.

${ }^{34}$ Muhammad Rasyîd Riḍâ, Tafsîr al-Manâr, Vol. 1 (t.t.p: alHay'ah al-Mișriyyah al-'Ầmmah Li al-Kitâb, 1990), 278.

${ }^{35}$ Jalaluddin Rakhmat stated that Rasyîd Riḍâs view need to be reviewed further. The reason is, the context conveyed by Rasyîd Riḍa is indeed talking about the faith of the previous peoples before the delegation of Prophet Muhammad. In his commentary, Rasyîd Riḍ̂ said:

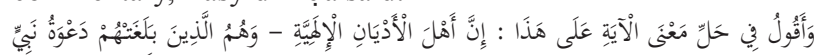

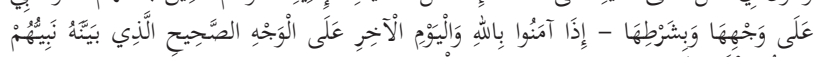

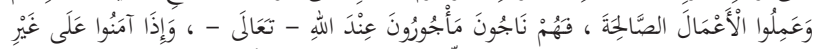

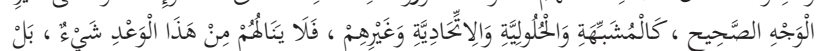

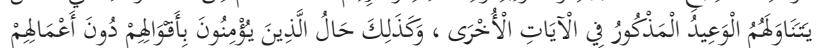

"Regarding the meaning of this verse, I say that the adherents of the religions of monotheism, namely those who accept the da'wah of the prophets in accordance with the teachings and conditions, if they believe in Allah SWT and the Last Day in the right way, according to what was explained by their prophet, and doing good deeds, then they are the ones who are safe and get their reward from Allah SWT. However, if they believe in an improper way, such as the sects of al-Musyabbihah, alHulûliyyah, al-Ittihâdiyyah and the like, then they will not get any reward. On the contrary (on the contrary), they will get the threat/torment that has been mentioned in other verses. Likewise, those who believe only with their words without their actions."(Muhammad Rasyîd Riḍâ, Tafsîr al-Manâr, Vol. 1 [t.t.p: al-Hay'ah al-Mișriyyah al-'Âmmah Li al-Kitâb, 1990], 281.) If Rasyîd Riḍâ's views are the same as those of Jalaluddin
}

To interpret QS. al-Baqarah: 62 that is in accordance with the message of the Qur'an and does not crash into other verses and hadiths; it will take steps as explained by al-Qara $\square$ âwî above that correlate with the QS. al-Baqarah: 62.

1. Interpreting the Qur'anic verses withother verses

To get the correct interpretation of QS. alBaqarah: 62 above, of course, its meaning must be in harmony with the meaning of other Qur'anic verses. In the rules of interpretation conveyed by al-Qara $\square$ âwî, this kind of interpretation is to interpret the verses of the Qur'an with other verses of the Qur'an.

Interpreting QS. al-Baqarah: 62 with a conclusion that all religions are the same and one day all of their adherents will go to heaven; then to be safe in the hereafter is not required to believe in Muhammad SAW. is against verses in the Qur'an that clearly show the necessity of believing in the Prophet Muhammad. as stated by the following verses:

a. QS. al-Baqarah: 177

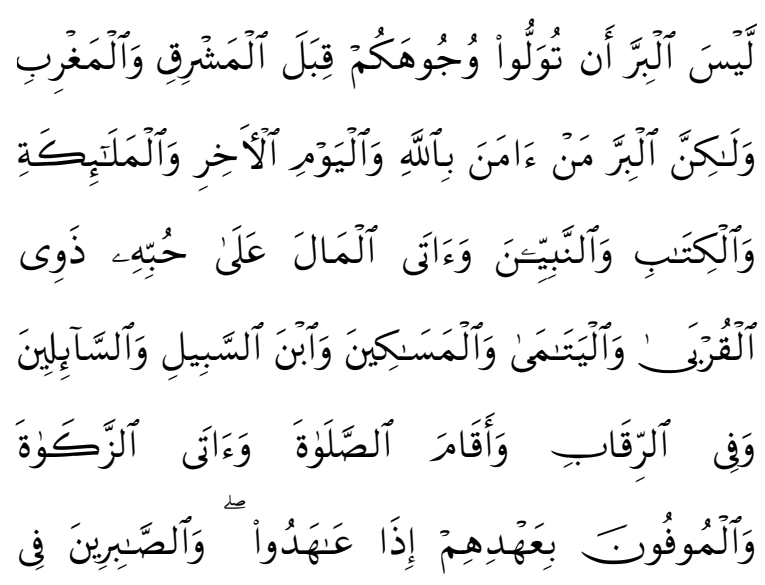

Rakhmat who adheres to the school of religious pluralism, then of course he will not criticize groups such as al-Musyabbihah, al-Hulûliyyah, al-Ittihâdiyyah and the like. On the other hand, when Rasyîd Riḍâ interprets QS.al-Ma'idah: 68, it confirms that Jews and Christians will not benefit from anything even though they attribute themselves to Moses, Jesus and the previous prophets so that they practice the Torah, the Gospel in which there is good news of the sending of the Prophet Muhammad and the Qur'an. (Muhammad Rasyîd Riḍâ, Tafsîr al-Manâr, Vol. 6 [t.t.p: al-Hay’ah al-Mișriyyah al-'Ammah Li al-Kitâb, 1990], 392.) 


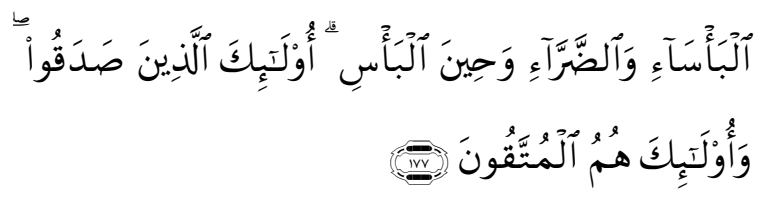

"It is not All-Birr (that reflects the true belief, acts that make men worthy of Paradise) that you turn your faces towards the East and the West, but All-Birr is (the quality of) the one who believes in Allah and the Last Day (the later day that one reaches Allah, the day of Guidance, spirit's returning to Allah) and the angels and the Book and the Prophets; and gives from his wealth that he loves to the kinsfolk, to the orphans, and to the needy (old folks who are incapable of working) and to the stranded, and to those who ask and to set slaves (captives) free, keeps up the Prayer, and gives the Zakat (the alms) and who fulfill their covenant when they make it (with Allah and men), and who are patient in extreme poverty and ailment and at the time of fighting (during the battles). Those are they who are truthful (veracious) and those are they who are the pious [the owners of piety (takwâ)]."

This verse states that one aspect of albirr (benevolence), apart from believing in Allah SWT and His angels, also believes in the books that Allah has revealed, and the prophets sent by Allah SWT., which includes the Prophet Muhammad.

b. QS. al-Baqarah: 285

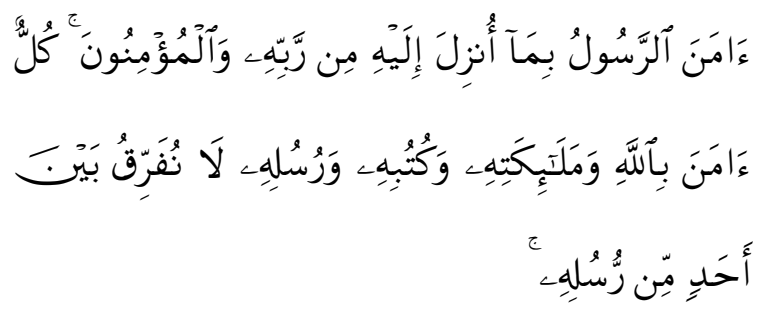

"The Messenger believes in what has been sent down to him from his Lord and (so do) the believers; they all believe in Allah and His angels and His books and His messengers; they say: "We make no distinction between any of His Messengers)."

This verse clearly shows that the criteria for believers are those who believe in Allah SWT, His angels, books, and messengers, do not discriminate between one messenger and another. Faith in messengers requires every believer to believe in all the messengers sent by Allah SWT. Thus, denying the apostleship of Muhammad will automatically revoke one's faith.

c. QS. al-Nisâ': 136

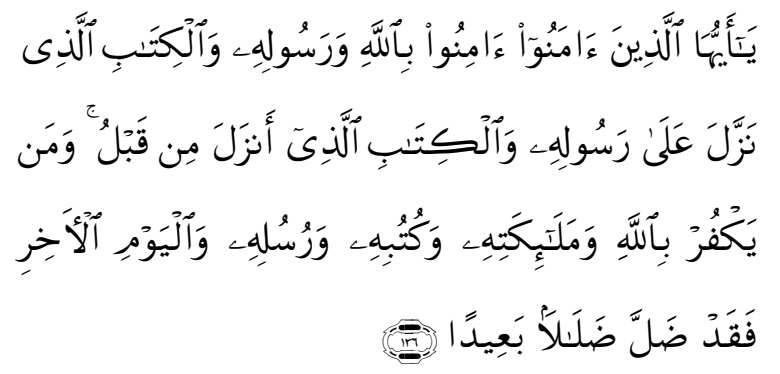

"O you who have believed, believe in Allah and His Messenger and the Book that He sent down upon His Messenger and the Scripture which He sent down before. And whoever disbelieves in Allah, His angels, His books, His messengers, and the Last Day has certainly gone far astray"

This verse is indeed addressed to Muslims, but the sentence "Whoever disbelieves in Allah, His angels, His books, His messengers, and the day after, then indeed that person has gone astray" is addressed to all mankind to believe in Allah, His angels, His books, His messengers (all apostles, including the Prophet Muhammad) and the Last Day. 
d. QS. al-Hadîd: 21

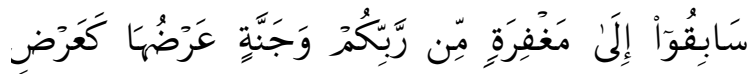

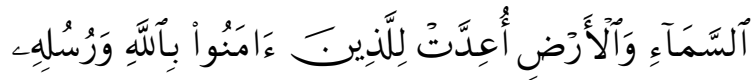

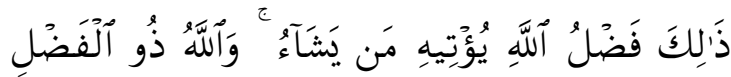

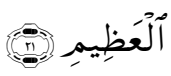

Race towards (to reach) Forgiveness from your Lord and heaven that the extensiveness of it is as the extensiveness of the sky and the earth which is prepared for those who believe in Allah and His Messenger. This is the Virtue of Allah. He gives it to whom He wills, and Allah is the Owner of Mighty Virtue."

This verse clearly states that forgiveness from God and heaven as wide as the heavens and the earth is only for those who believe in Allah and all His Messengers, without exception.

e. QS. al-Nisâ': 150-152

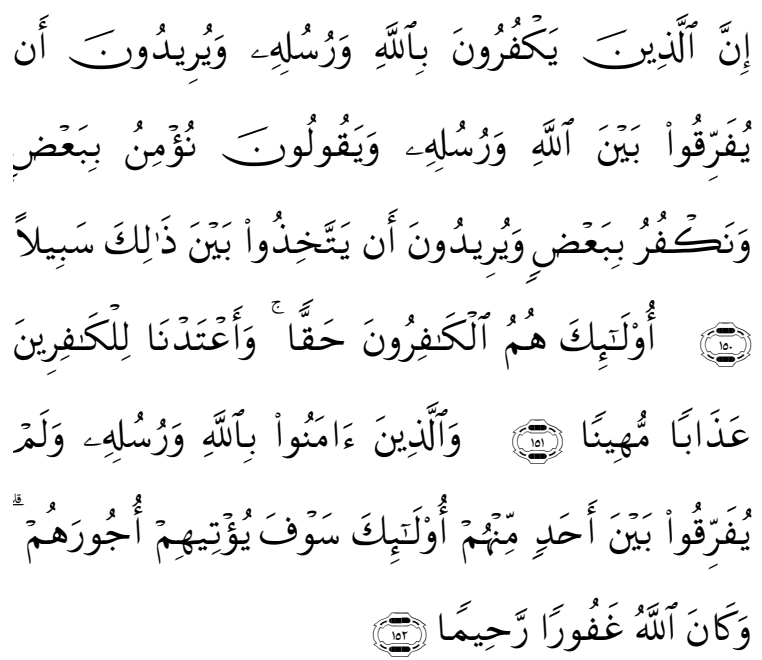

"There are those who disbelieve in Allah and His Messengers and seek to differentiate between Allah and His Messengers, and say: 'We believe in some and deny others, and seek to strike away between the two' (4:150). It is they, indeed they, who are, beyond all doubt, unbelievers; and for the unbelievers, we have prepared a humiliating hastisement (4:151). For those who believe in Allah and His Messengers, and do not differentiate between them, We shall certainly give them their reward. Allah is All-Forgiving, All-Compassionate" (4:152).

This verse clearly explains that those who distinguish between belief in Allah and His messengers are true disbelievers, and Allah will punish them. On the other hand, for those who believe in Allah and His Messengers without discriminating between any of them, Allah will reward them.

2. Interpreting the verses of the Qur'an with an authentic (sahih) hadith

The other principle used by al-Qaradâwî to get the proper interpretation is to interpret the verses of the Qur'an with the sahih hadith of the Prophet. In this regard, a harmonization of the meaning of the verse is necessary so that it does not conflict with the authentic hadiths. Thus, the hadith of the Prophet explains the obligation to believe in the Prophet Muhammad as an aspect of faith and a condition of salvation in the hereafter:

a. Hadith narrated by 'Umar bin al-Khattab, which is famous for the hadith of Gabriel, when he asked the Messenger of Allah about faith, then the Prophet replied:

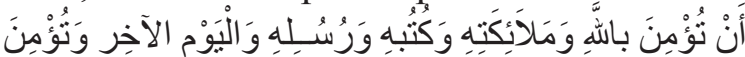

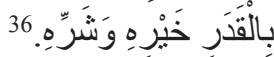

"Faith is that you believe in Allah SWT., His angels, His books, His messengers, the Last Day and believe in His qadar, both good and bad."

This hadith confirms that faith in the messenger is stated in the plural form. That

${ }^{36}$ Muslim bin al-Hajjâj al-Naisâbûrî, al-Jâmi ‘ al-Sahị̂h, Vol. 1 (Beirut: Dâr al-Jail, n.d.), 28. 
means believing in the messengers includes all the messengers, without exception. Of course, including a belief in the apostleship of Muhammad.

b. Hadith narrated by Abû Hurayrah, where the Messenger of Allah said:

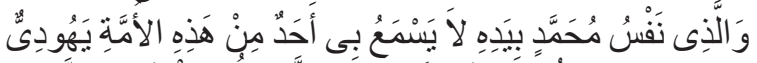

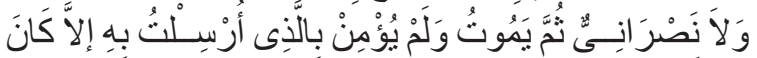
مِنْ أَصْحَاب النَّار .

"By the One who holds the soul of Muhammad, no one heard me from this ummah, whether Jews or Christians, then he died and did not believe in the treatise that I brought except he will be one of the inhabitants of hell."

This hadith very clearly shows that Jews, Christians, and anyone who encounters, hears, and knows the Messenger of Allah must believe and follow the Prophet Muhammad. Al-Nawawî, who commented on this hadith, said that this hadith shows that the treatise of the Prophet Muhammad annulled (naskh), the treatises of the previous religions.

According to al-Nawawî, hâdzihi alummah in the above hadith are all people in the time of the Prophet and the period after him until the Day of Judgment. They are all obliged to obey the Prophet. The statement of Jews and Christians in the above hadith is merely a warning for other than Jews and Christians. If the religions with revelation are still required to believe in the Prophet Muhammad, other religions with no revelation are more necessary. ${ }^{38}$

c. Hadith narrated by Abu Mûsâ al-Asy'arî, the Prophetsaid:

${ }^{37}$ Ibid., 93 .

${ }^{38}$ Yahyâ bin Syaraf al-Nawawî, al-Minhâj Syarh Shahîh Muslim bin al-Hajjâj, Vol. 1 (Beirut: Dâr Ihyâ' al-Turâts al-'Arabî, 1392),279.

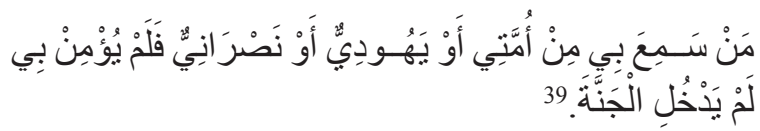

"Whoever from my Ummah or Jews or Christians hear me but do not believe in me, they will not enter Paradise."

In another narration from Abû Mûsâ alAsy'arî, the Prophet said:

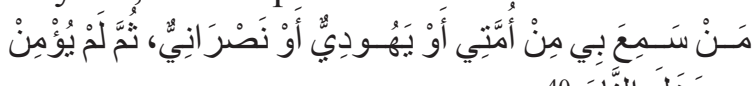

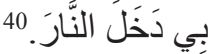

"Whoever from my Ummah or Jews or Christians hear me and do not believe in me, then they will go to hell."

d. Hadith narrated by Ibn 'Abbâs that the Prophet said:

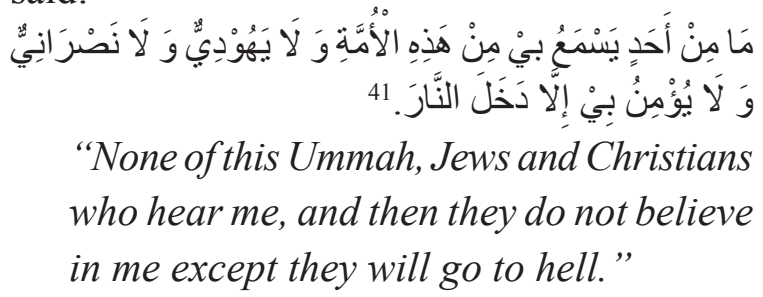

This hadith, like the previous hadiths, states that faith in Muhammad SAW is one of the conditions of salvation in the hereafter and is a ticket to enter paradise.

3. Using the interpretations of the Companions and Tabi'in

Interpreting QS. al-Baqarah: 62 above also needs to consider the interpretation of the salaf ulama, both from companions and the tabi'in. Ibn Jarîr al-Ṭabarî, after explaining the meaning of Judaism, Christianity, and Sabian, then said that the faith of Jews, Christians, and Sabians is by tașdîq (justifying) to Muhammad and his treatise.Thus according to al-Ṭabarî, whoever believes among them in Muhammad and his

${ }^{39}$ Ahmad bin Hanbal al-Syaibânî, Musnad Ahmad bin Hanbal, Vol. 32 (Beirut: Mu'assasah al-Risâlah, n.d.), 305.

${ }^{40}$ Ibid., 332.

${ }^{41}$ Al-Hâkim al-Naysâbûrî, al-Mustadrak 'Alâal-șahîhayn, Vol. 2 (Beirut: Dâr al-Kutub al-'Ilmiyyah, 1990), 372. 
treatise, believes in the Last Day and does good deeds, does not change his religious teachings until he dies, he will get the reward of his deeds from Allah SWT. ${ }^{42}$ Al-Tabarî then quotes the interpretations of al-Suddî (127 H.) and Mujâhid (21-104 H.), who argue that a Jew's faith is when he holds firmly to the Torah and the sunnah of Moses until Jesus came. After Jesus, those who adhered to the Torah and the Sunnah of Moses and didn't follow Jesus will go astray. Then, the faith of a Christian is when that person adheres to the Bible and the Shari'a of Jesus until Muhammad SAW comes. After Muhammad, anyone who does not follow him and does not leave the Shari'a of Jesus and the Bible will also go astray. ${ }^{43}$ While Ibn'Abbâs and Sa'îd bin 'Abd al-'Azîz argue that QS. al-Baqarah: 62 has been annulled by QS. 'Alî Imrân: $85{ }^{44}$

Through this verse, Ibn Katsîr explained that Allah SWT emphasized that every person from the previous peoples who does good and obeys will get a good reward until the Day of Judgment. Everyone who follows Prophet Muhammad will get eternal salvation. ${ }^{45}$ Ibn Katsîr then quotes the opinion of al-Suddî and Ibn Jubayr regarding the verse as conveyed by Ibn Jarîr above. ${ }^{46}$ According to Ibn Katsîr, al-Suddî's view does not contradict the idea of Ibn 'Abbâs, who said that after the descent of al-Baqarah: 62, Allah SWT revealed QS. 'Alî Imrân: 85, ${ }^{47}$ because the opinion of Ibn 'Abbâs is an ikhbâr (news) that there is no one way and charity that is accepted except in accordance with the Shari'a of the Prophet Muhammad after Allah SWT sent him with his treatise. Before the prophethood of Muhammad,

\footnotetext{
${ }^{42}$ IbnJarîral-Ṭabarî, Jâmi ' al-Bayân fî̀ Tafsîr al-Qur'ân, Vol. 2 (t.t.p.: Dâr Hijr, n.d.),39.

${ }^{43}$ Ibid., 44-45.

${ }^{44}$ Ibid., 45-46.

${ }^{45}$ Ibn Katsîr, Tafsîr al-Qur' ân al- 'Azîim, Vol. 1 (t.t.p: DârṬayyibah, 1999), 184.

${ }^{46}$ Ibid.

${ }^{47}$ QS. 'Alî Imrân: 85:

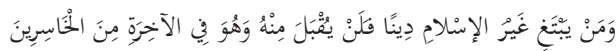
"Whoever seeks a way other than Islam, it will never be accepted from them, and in the Hereafter they will be among the losers."
}

everyone who followed the apostle in his day was on guidance, the right path, and salvation. ${ }^{48}$ Thus, when Allah SWT sent Muhammad as the last prophet and messenger to the descendants of Adam, it is obligatory to justify the treatise of Muhammad SAW, obey his orders, and stay away from his prohibitions. Such people are called true believers. $^{49}$

4. Considering the redaction of the verse

QS. al-Baqarah: 62 is in line with the QS. alMâ'idah: 69 as follows:

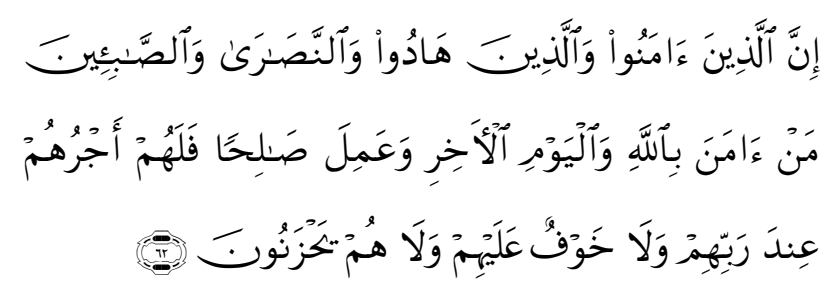

"Verily the believers, the Jews, the Sabians, and the Christians, whoever believes in Allah, in the Last Day, and does good deeds, thus there is no fear for them nor will they grieve."

To get the whole meaning related to QS. alMâ'idah: 69 above, then the previous two verses should not be neglected. Two verses before QS. al-Mâ'idah: 69 above are as follows:

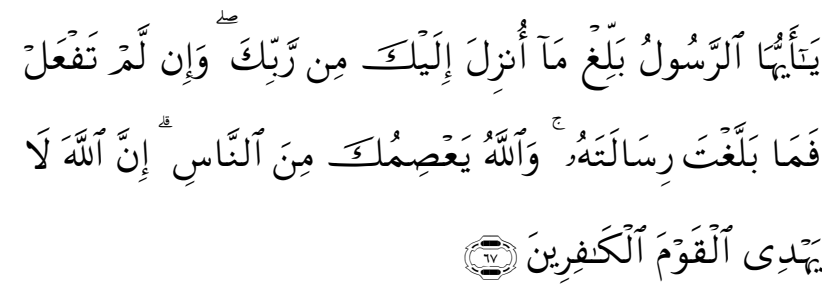

"O Messenger! Convey everything revealed to you from your Lord. If you do not, then you have not delivered His message. Allah will 'certainly' protect you from the people. Indeed, Allah does not guide the people who disbelieve” [QS. al-Mâ'idah: 67].

\footnotetext{
${ }^{48}$ Ibn Katsîr, Tafsîr al-Qur'ân al-'Aẓ̂m, Vol. 1 (t.t.p: Dâr Tayyibah, 1999), 185.

${ }^{49}$ Ibid., 184.
} 


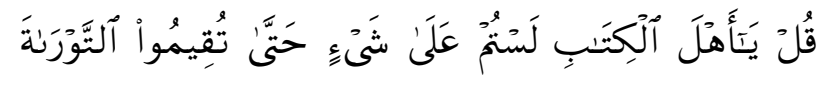

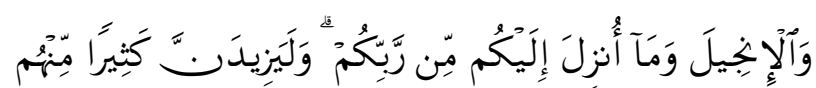

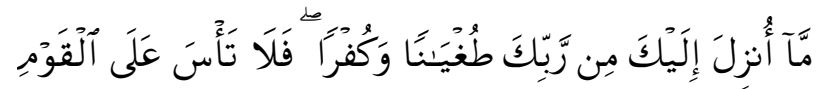

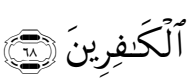

"Say, 'O Prophet,' 'O People of the Book! You have nothing to stand on unless you observe the Torah, the Gospel, and what has been revealed to you from your Lord." And your Lord's revelation to you 'O Prophet' will only cause many of them to increase in wickedness and disbelief. So do not grieve for the people who disbelieve" [QS. al-Mâ'idah: 68].

QS. al-Mâ'idah: 67 contains a message to the Prophet Muhammad to convey what Allah SWT has revealed. If he did not convey it, it means he did not convey the message of Allah SWT. While the next verse, QS. al-Mâ'idah: 68 commanded the Prophet Muhammad to convey to the People of the Book (Jews and Christians) that they are not considered as adherents so that they uphold the teachings of the Torah, the Gospel, and what Allah SWT has revealed to the Prophet Muhammad, namely the Qur'an. It means Jews and Christians must believe in the Prophet Muhammad and the Qur'an.

Al-Tabarî stated that this verse is a command from Allah SWT to the Prophet Muhammad to convey to the Jews and Christians that they will not get anything even though they claim to be the followers of Moses for the Jews and the followers of Jesus for the Christians so that they uphold the Torah, the Gospel and what was revealed to them from Allah that is the Qur'an which was brought by the Prophet Muhammad. Then they practiced it and believed in what was in it in the form of faith in Muhammad and justified it. They also have to believe that it all comes from Allah. Jews and Christians cannot deny anything from the Qur'an, and they cannot distinguish among
Allah's messengers. They are not supposed to believe in some and disbelieve others because disbelief in one messenger is essentially disbelief in all of them. These are all messages from Allah's books that mutually justify one another. Whoever denies one of them, he has rejected all of them. ${ }^{50}$

\section{Considering asbâb al-nuzĥl (Reason of revelation)}

Based on the narrations of al-Suddî and Mujâhid, as quoted by Ibn Jarîr and also Ibn Katsir, the reason for the revelation of QS. alBaqarah: 62 is when Salman asked the Prophet about the fate of the Christians and their deeds. Rasulullah SAW told him that they did not die in the state of Islam. It made Salman sad, so the verse was revealed. The Prophet then called Salman and said that this verse was revealed to the companions of Salman. Whoever dies in the religion of Jesus and dies in the time of Islam before hearing about me, then he is in goodness. Whoever hears about me today, but does not believe in me, then he is in misery. ${ }^{51}$

While asbâb al-nuzûl QS. al-Mâ'idah: 68, as narrated by Ibn Ishaq, al-Ṭabarî, Ibn al-Mundzîr, Ibn Ab Hâtim, and Ab al-Shaykh, from the path of Ibn 'Abbâs, this verse was revealed hen Râfi' bin Hâritsah, Salâm bin Misykam, Mâlik bin al-Syaif, and Râfi' bin Huraymilah said to the Prophet: "O Muhammad, are not you following millah and religion of Ibrahim, you also believe in what is on our side, namely the Torah and you testify that the Torah is true from Allah SWT.?" Rasulullah SAW then replied: "That's right. But you have changed and contradicted what is in the Torah in the form of a promise made to you, and you have hidden something from the Torah which you are commanded to explain to mankind. For that, I am free from what you have done." They said: "We

\footnotetext{
${ }^{50}$ Ibn Jarîr al-Ṭabarî, Jâmi “ al-Bayân fí Tafsîr al-Qur'ân, Vol 8 (t.t.p: Dâr Hijr, n.d.), 572.

${ }^{51}$ Ibn Jarîr al-Ṭabarî, Jâmi “ al-Bayân fì Tafsîr al-Qur' ân, Vol. 2 (t.t.p: Dâr Hijr, n.d.),45; Ibn Katsîr, Tafsîr al-Qur'ân al-'Azîm, Vol. 1 (t.t.p: Dâr Ṭayyibah, 1999), 284.
} 
took what was with us. Therefore, we are in the truth and guidance. We will not believe in you and will not follow you." Then Allah SWT revealed QS. al-Mâ'idah: 68 to them. ${ }^{52}$ This verse certainly emphasizes that Jews and Christians must believe in the Prophet Muhammad and the Qur'an.

Faith in all the messengers of Allah SWT is a fundamental Islamic creed, so denying just one apostle is considered to refuse all of them. Many verses of the Qur'an confirm this. For example, in QS. al-Syu 'arâ': 105, ${ }^{53}$ Noah's people are considered to have denied all the apostles, even though they only rejected Noah. The people of 'Ad are also similar; they are considered to have denied Allah SWT's messengers, even though they only denied the Prophet Hud, as stated in the QS. Syu'arâ': $123 .{ }^{54}$ The Thamud are also considered to have denied all of Allah's messengers, even though they only rejected the Prophet Shalih. The same thing happened to the people of Luth ${ }^{55}$ and the Syu'ayb. ${ }^{56}$

In addition, as it is generally known, the Prophet Muhammad was sent by bringing his treatise intended for all humankind, not only for the Arabs, the origin and growth of Muhammad. Prophet Muhammad SAW is also delegated for the Jews, Christians, and other peoples because they are all part of the human race to get guidance and avoid misguidance. It is darûrî (certain) in Islam. The arguments for this are many and clear. ${ }^{57}$

\footnotetext{
${ }^{52}$ Ibn Jarîr al-Ṭabarî, Jâmi ' al-Bayân fî Tafsîr al-Qur'ân, Vol. 8 (t.t.p: Dâr Hijr, n.d.), 572. See also 'Abdurrahmân bin Abî Bakr al-Suyûțî, al-Durr al-Mantsûr Fî al-Tafsîr Bi al-Ma'tsûr, Vol. 5 (Mesir: Dâr Hijr, 2003),389.

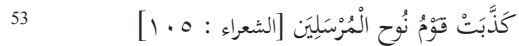

"Noah's people have denied the apostles."

54

"“Ad people have denied the apostles."

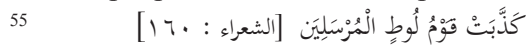

"Luth's people have denied the apostles."

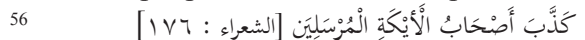

"The people ofAikah have denied the apostles."

Yûsuf al-Qaraḍ̂wî, Mawqîf al-Islâm al-'Aqadî Min Kufr alYahûd wa al-Nașârâ (t.t.p: Mu'assasah al-Risâlah, n.d.), 28.

${ }^{57}$ See also:

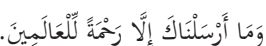

"And We have not sent you, but to be a mercy for the worlds" [QS. al-Anbiya': 107].

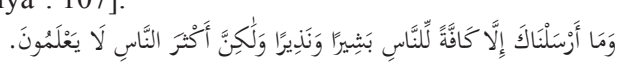

If the Jews, Christians, and followers of other religions were in the truth and would later go to paradise, the Prophet Muhammad would not have called them to convert to Islam through the da'wah carried out by the Prophet starting from the Mecca phase until the Prophet died in Medina. The Prophet's Letters to the rulers of Rome, Persia, Egypt, Habasyah, Hadhramaut, Bahrain, and others inviting them to embrace Islam would be meaningless and useless if they were on the right path and will someday go to heaven.

\section{Conclusion}

QS. al-Baqarah: 62 talks about the earlier peoples before the Prophet Muhammad. Those who believe in Allah and the Last Day and do good deeds are promised a reward by Allah SWT. This conclusion is obtained from interpreting QS. al-Baqarah: 62 with other verses of the Qur'an, Hadiths of the Prophet SAW, interpretation of the Companions, considering the redaction of the verse and asbâb al-nuzûl. Interpreting QS. al-Baqarah: 62 by stating that Jews, Christians, Sabians and followers of other religions who believe in Allah SWT and the Last Day, as well as doing good deeds will later enter paradise is an interpretation against many verses and hadiths which show that those who do not believe in Prophet Muhammad SAW and his message (the Qur'an) will not get salvation.

The interpretation of these verses must be returned and harmonized with other verses and hadiths that have a clearer dalâlah (muhkam) to match the messages brought by the Qur'an itself. Not contrarily, ignoring some verses and hadiths that show clear meanings and then falling into mutasyâbih verses so that the result of their interpretation contradicts other verses and hadiths. Essentially, the verses of the Qur'an and

\footnotetext{
"We have sent you 'O Prophet' only as a deliverer of good news and a warner to all of humanity, but most people do not know" [QS. Sabâ': 28].

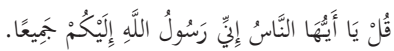
"Say: "O mankind, indeed I am Allah's messenger to you all" [QS. al-A'râf: 158] and so on.
} 
the hadith are not contradictory because they all come from the same source, from Allah SWT.

Judging Jews, Christians, and followers of other religions as a deviant group and will not be safe in the future as they do not believe in Muhammad SAW and the Qur'an does not mean that we can act rudely to them. The Qur'an has taught Muslims to do justice to everyone, even to the enemy. Prophet SAW himself had given an example of the ukhuwwah insâniyyah (human brotherhood) that he built with other communities in Medina. In a story, when a Jewish corpse passed by, the Prophet spontaneously stood up as a form of respect for the corpse as a fellow human being, a descendant of Adam and a servant of Allah. Again, one day when the Prophet received a group of Najrân Christians, the Prophet received them in the mosque and even invited them to perform their worship in the mosque. These prove that Islamic teaching regarding interaction with followers of other religions emphasizes peace, not war. History has revealed that the Prophet never fights non-Muslims just because they are nonMuslims. Even in a hadith, the Prophet threatens Muslims who disturb the dzimmis and mu'âhad with the threat that they will not smell the smell of heaven which can be smelled within a radius of forty years of travel.

\section{References}

'Arabî, Ibn. Fuṣ̂ș al-Hikam. T.t.p: Dâr al-Kitâb al-'Arabî, n.d.

al-Bukhârî, Muhammad bin Ismâ‘îl. al-Jâmi ‘ alSahîh. Vol. 2. Kairo: Dâr al-Sya ‘b, 1987. . al-Jâmi’ al-Sahîhh. Vol. 9. Kairo: Dâr al-Sya'b, 1987.

al-Jawziyyah, Ibn al-Qayyim. Zâd al-Ma'âd Fî̀ Hady Khayr al-'Ibâd. Vol. 3. Beirut: Mu'assasah al-Risâlah, 1994.

al-Naisâbûrî, al-Hâkim. Al-Mustadrak 'Alâ alȘahîhayn. Vol. 2. Beirut: Dâr al-Kutub al-'Ilmiyyah, 1990.
al-Naisâbûrî, Muslim bin al-Hajjâj. Al-Jâmi * al-Șahîh. Vol. 1. Beirut: Dâr al-Jayl, n.d. al-Namirî, Yûsuf bin 'Abd al-Barr. Jâmi ' Bayân al- 'Ilm wa Fadlih. Vol. 2. Beirut: Dâr alKutub al-'Ilmiyyah, $1398 \mathrm{H}$.

al-Nawawî, Yahyâ bin Syaraf. Al-Minhâj Syarḥ Sahîh Muslim bin al-Hajjâj. Vol. 1. Beirut: Dâr Ihyâ' al-Turâts al-'Arabî, 1392 H.

al-Qarḍ̂wwî, Muhammad Yûsuf. Kayfa Nata 'âmal Ma ' al-Qur'ân al- 'Azî̀m. Kairo: Dâr alSyurûq, 1999. . al-Marja 'iyyah al- 'Ulyâ Fîal-Islâm Li al-Qur'ân wa al-Sunnah. Kairo: Maktabah Wahbah, 2012. . Mawqîf al-Islâm al- 'Aqadî Min KufralYahûd wa al-Nashârâ. T.t.p: Mu'assasah al-Risâlah, n.d.

. Tafsîr Juz' 'Amma. t.t.p: t.p., n.d.

al-Suyûțî, 'Abdurraḥmân bin Abî Bakr. Al-Durr al-Mantsûr Fî al-Tafsîr Bi al-Ma'tsûr. Vol. 5.Mesir: Dâr Hijr, 2003.

al-Syaibânî, Aḥmad bin Ḥanbal. Musnad Aḥmad bin Hanbal. Vol. 32. Beirut: Mu'assasah al-Risâlah, n.d.

al-Syaukânî, Muhammad bin 'Alî. Fatḥ al-Qadîr al-Jâmi` BainaFannî al-Riwâyahwa alDirâyah min 'Ilm al-Tafsîr. Beirut: Dâr al-Ma'rifah, 2007.

al-Ṭabarî, Ibn Jarîr. Jâmi ' al-Bayân fì Tafsîr alQur'ân. Vol. 2. T.t.p: Dâr Hijr, n.d.

Departemen Agama Repubik Indonesia. AlQur'ân Digital Versi 2.0. 2004.

Faḍhlullâh, Sayyid Huseyn. Tafsîr min Wahy al-Qur'ân. Vol. 2. Beirut: Dâr al-Malâk, 1998.

Fanani, Zahrodin. "Pandangan Muhammad Rasyid Ridha Terhadap Pluralisme Agama dalam Tafsir al-Manar". Tesis. Program Pascasarjana Universitas Muhammadiyah Surakarta, 2013.

Fata, Ahmad Khoirul dan Fauzan, "Kritik INSISTS terhadap Gagasan Pluralisme Agama”. Kalam 11, No. 1 (2017): 5354. 
Goldziher, Ignaz. Madzâhib al-Tafsîr al-Islâmî. Ed. 'Abd al-Halîm al-Najjâr. Kairo: Maktabahal-Sunnah al-Muhammadiyyah, 1955.

Hajar, Siti and Umayah. "Tafsir Ayat-ayat Pluralisme Agama Perspektif Husein Muhammad". Diyấ'Al-Afkâr 8, No. 02 (2020): 247.

https://www.al-Qaradâwî. net/content/\%D8\%A 7\%D9\%84\%D8\%B3\%D9\%8A\%D8\%B1 \%D8\%A9-\%D8\%A7\%D9\%84\%D8\%B0 \%D8\%A7\%D8\%AA\%D9\%8A\%D8\%A9 https://www.youtube.com/watch? $v=$ 1Zqyo5xhXsk

Katsîr, Ibn. Tafsîr al-Qur'ân al-'Azînm. Vol. 1. T.t.p: Dâr Thayyibah, 1999.

Mukhoyaroh, Fadliyatul dan Saifullah, "Pluralisme Agama Perspektif Tafsir Al-Misbah karya Muhammad Quraish Shihab". Multicultural 2, No. 2 (2019): 58. Rakhmat, Jalaluddin. Islam dan Pluralisme:
Akhlak Quran Menyikapi Perbedaan. Jakarta: Serambi, 2006.

Riḍ̂, Muhammad Rasyîd. Tafsîr al-Manâr Vol. 1. T.t.p: al-Hay'ah al-Mișriyyah al'Âmmah Li al-Kitâb, 1990.

Sirry, Mun'im. "Islam, LGBT Dan Perkawinan Sejenis". TEMPO.CO https://indonesiana. tempo.co/read/64822/2016/03/02/masirry/ islam-lgbt-dan-perkawinan-sejenis

Syam, Nur. "Sekali Lagi Pluralisme Gus Dur." http://nursyam.uinsby.ac.id/?p=879

Syukri, Muhammad. "Pluralisme dalam Perspektif Mufassirin". Tesis. Program Pascsarjana UIN Syarif Kasim Riau, 2017.

Umami, Faidah. "Pluralisme Agama dalam alQur'an (Komparasi Pemikiran Abdul Muqsith Ghazali dengan Ali Mustafa Ya'qub terhadap Ayat-ayat Pluralistik". Tesis. Program Pascasarjana IAIN Sunan Ampel, 2013. 